\title{
Erratum to: Sub-volcanic Intrusions in the Karoo Basin, South Africa
}

Henrik H. Svensen, Stéphane Polteau, Grant Cawthorn, and Sverre Planke

\section{Erratum to: Advances in Volcanology DOI: 10.1007/11157_2014_7}

The chapter was inadvertently published without updating Table 1. The erratum chapter has been updated with the change.

The updated original online version for this chapter can be found at 10.1007/11157_2014_7

H.H. Svensen $(\square) \cdot$ S. Planke

Centre for Earth Evolution and Dynamics (CEED), University of Oslo, Oslo, Norway

e-mail: hensven@fys.uio.no

S. Polteau $\cdot$ S. Planke

Volcanic Basin Petroleum Research (VBPR), Oslo Innovation Center, Oslo, Norway

G. Cawthorn

School of Geosciences, University of Witwatersrand, Johannesburg, South Africa 